\title{
APPLICATION OF SOLAR CELLS MADE OF DIFFERENT MATERIALS IN 1 MW PV SOLAR PLANTS IN BANJA LUKA
}

\author{
T. Pavlović", D. Milosavljević, I. Radonjić, L. Pantić, A. Radivojević \\ Faculty of Sciences and Mathematics, University of Niš, \\ Višegradska 33, 18000 Niš, Republic of Serbia
}

\begin{abstract}
The paper outlines the energy efficiencies of the fixed, one-axis and dualaxis tracking $1 \mathrm{MW}$ PV solar plant with monocrystalline silicon, thin film CdTe and CuIn$\mathrm{Se}_{2}$ (CIS) solar cells in Banja Luka. Special attention is paid to physical characteristics of monocrystalline silicon solar cells, CdTe and CIS solar cells and their application in PV solar plants. For the calculation of the energy efficiency of PV solar plants PVGIS program was used.
\end{abstract}

Keywords: solar energy, solar cells, PV solar plant.

\section{INTRODUCTION}

Since the outbreak of the world economic crisis in 1973, the use of solar cells for the electricity generation has been more and more in the focus of attention. Worldwide, more than 1600 PV solar plants of smaller or greater power have been installed on the ground. Most developed countries legally regulate the possibility of generating and selling of the electrical energy generated in PV solar plants. The use of solar energy contributes to more efficient use of a countrys' own potentials in producing electrical and thermal energy, reduction of the greenhouse gas emission, lowering of the import rates and the use of fossil fuels, as well as to the development of the local industries and an increase in new job creation.

PV solar plants mostly use solar modules made of monocrystalline and polycrystalline silicon and solar modules made of thin film materials such as amorphous silicon, CdTe and CopperIndium-Deselenide (CIS, CuInSe $e_{2}$ ). Efficiency of monocrystalline silicon solar cells is $15 \%$, of polycrystalline silicon is about $12 \%$, of amorphous silicon about $5 \%$ and those made of CdTe and CIS is about $8 \%$. Monocrystalline and polycrystalline silicon solar modules are more suitable for the areas with predominantly direct sun radiation, while solar modules of thin film are more suitable for the areas with predominantly diffuse sun irradiation $[1,2]$.

\footnotetext{
*Corresponding author: pavlovic@pmf.ni.ac.rs
}

\section{SOLAR CELLS}

A solar cell is composed of $p$ and $n$ semiconductors where, due to the absorption of sun irradiation in a $p-n$ connection, pairs of electronhole occur. Under the influence of sun irradiation, a solar cell in electrical circuit represents the source of direct current (DC).

\section{Solar cells of monocrystalline silicon}

Silicon, which, next to oxygen, is the most represented element in the earth's crust $(27.6 \%)$ is used for the production of monocrystalline silicon solar cells. Silicon belongs to the group IV of the periodic system of elements, it is easily obtained and processed, it is not toxic and does not form compounds that would be environmentally harmful. In contemporary electronic industry silicon is the main semiconducting element. Electronic components made of silicon are stabile at temperatures up to $200^{\circ} \mathrm{C}$.

Semiconducting silicon is polycristalline. For it to be converted into monocristalline it has to be melted at $1400^{\circ} \mathrm{C}$ and by means of Czochralski process, or by method of float zone, converted into monocrystalline. Atoms of monocrystalline silicon are connected mutually by covalent bonds into surface centered crucible. Monocrystalline silicon is black, non-transparent, very shiny, hard and a weak conductor of electricity. With some additional substances monocrystalline silicon becomes a good conductor of electric current. 
A solar cell composed of monocrystalline silicon has a front electrode, an antireflection layer, an n-layer, $\mathrm{p}$-n bond, p-layer and back electrode (Fig.1). In order to obtain semiconductor of n-type, silicon is doped with phosphorous, and to obtain semiconductor of p-type, silicon is doped with boron. P-layer is $300 \mu \mathrm{m}$ thick, while n-layer is $0,2 \mu \mathrm{m}$ thick. For antireflection layer, materials with refraction index of 1,5-2 are used. These materials comprise $\mathrm{SiO}, \mathrm{SiO}_{2}, \mathrm{TiO}, \mathrm{TiO}_{2} \mathrm{Ta}_{2} \mathrm{O}_{3}$, etc. Depending on the antireflection layer material, monocrystalline solar cells of different colours can be produced. Metal contacts are formed by vacuum vaporing of the corresponding materials on Si plate. For this purpose, $\mathrm{Ti} / \mathrm{Pd} / \mathrm{Ag}$ coating is usually used.

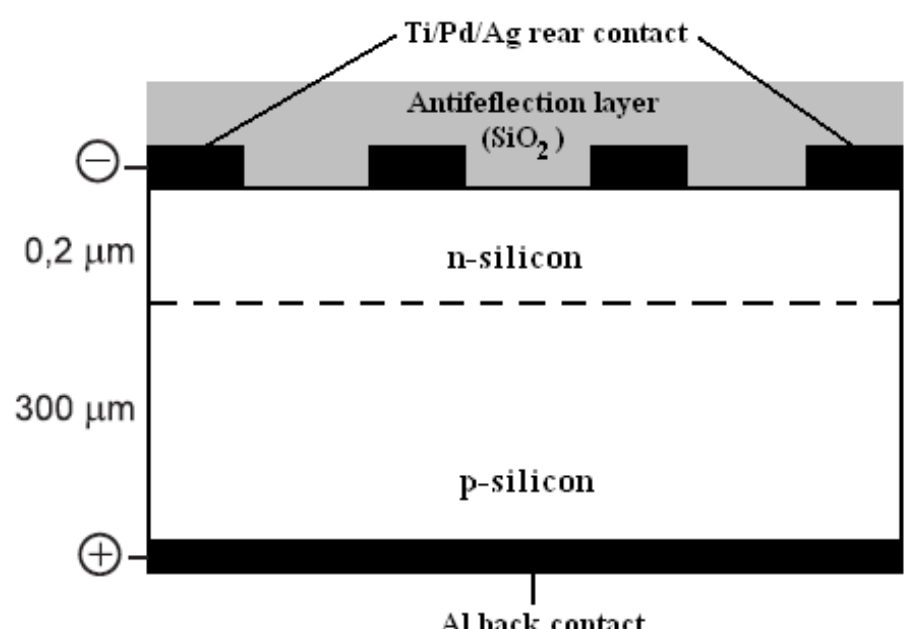

Figure 1. Schematic cross section of solar cell made of monocrystalline silicon

Monocrystalline silicon solar cell is sensitive to wavelengths of $0,4-1,1 \mu \mathrm{m}$, and its maximum sensitivity is within the range of $0,8-0,9 \mu \mathrm{m}$. Maximum of spectral sensitivity of the monocrystalline silicon solar cell does not coincide with the maximum of spectral distribution of sun irradiation. Commercial monocrystalline silicon solar cells have the efficiency of $15 \%$, and laboratory ones about 24\% [2-3].

\section{CdTe solar cells}

Cross section for a cadmium telluride solar cell is shown in Fig. 2. A layer of cadmium sulphide is deposited from solution onto a glass sheet coated with a transparent conducting layer of thin oxide. This is followed by the deposition of the main cadmium telluride cell by a variety of techniques including close-spaced sublimation, vapor transport, chemical spraying, or electroplating.

CdTe solar cells have been used as low cost, high efficiency, thin-film photovoltaic applications since 1970. With the forbidden zone width of $1,5 \mathrm{eV}$ and the coefficient of absorption $\sim 10^{5} \mathrm{~cm}^{-}$ 1 , which means that a layer thickness of a few micrometers is sufficient to absorb $\sim 90 \%$ of the inci- dent photons, CdTe is almost an ideal material for manufacturing of solar cells.

CdTe solar cells are sensitive in the wavelength of $0,3-0,95 \mu \mathrm{m}$ with their maximum sensitivity within the wavelength range of $0,7-0,8$ $\mu \mathrm{m}$. Laboratory CdTe cells have the efficiency of $16 \%$, and commercial ones around 8\%. High toxicity of tellure (tellurium) and its limited natural reserves diminish the prospective development and application of these cells [4-7].

\section{CIS solar cells}

The materials based on $\mathrm{CuInSe}_{2}$ that are of interest for photovoltaic applications include several elements from groups I, III and VI in the periodic table. CIS is an abbreviation for general chalcopyrite films of copper indium selenide $\left(\mathrm{CuInSe}_{2}\right)$.

CIS technology is a star performer in the laboratory with $19,5 \%$ efficiency demonstrated for small cells, but has proved difficult to commercialize. Unlike the other thin-film technologies, which are deposited onto a glass substrate, CIS technology generally involves deposition onto a glass substrate as shown in Fig. 3. An additional glass top-cover is then laminated to the 
cell/substrate combination. Present designs require a thin layer of CdS deposited from solution. Considerable effort is being directed to replacing this layer due to the issues associated with the use of cadmium, as previously noted. However, a long- term issue with CIS technology is one of available resources. All known reserves of indium would only produce enough solar cells to provide a capacity equal to all present wind generators.

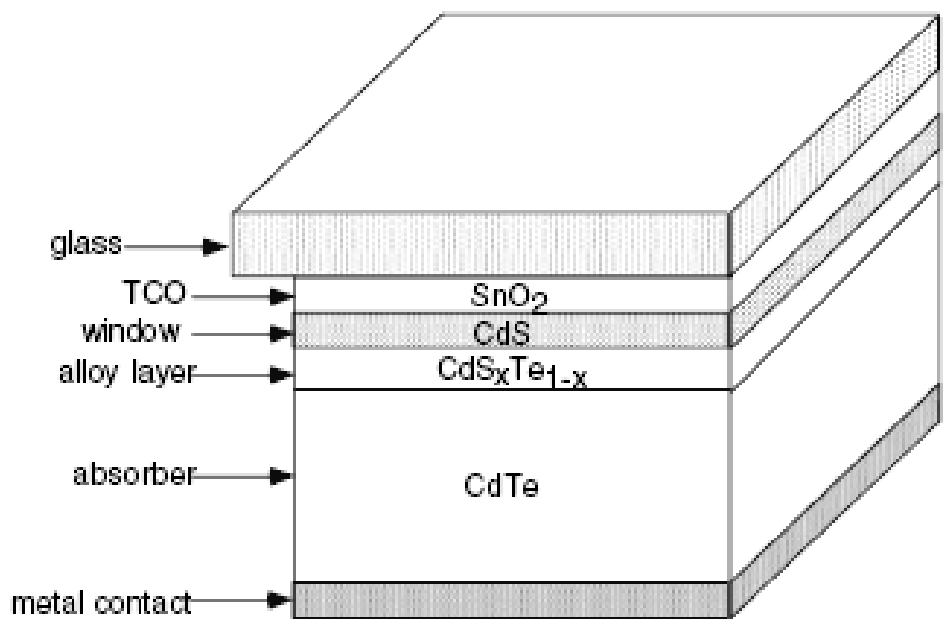

Figure 2. A cross section of solar cell made of cadmium telluride

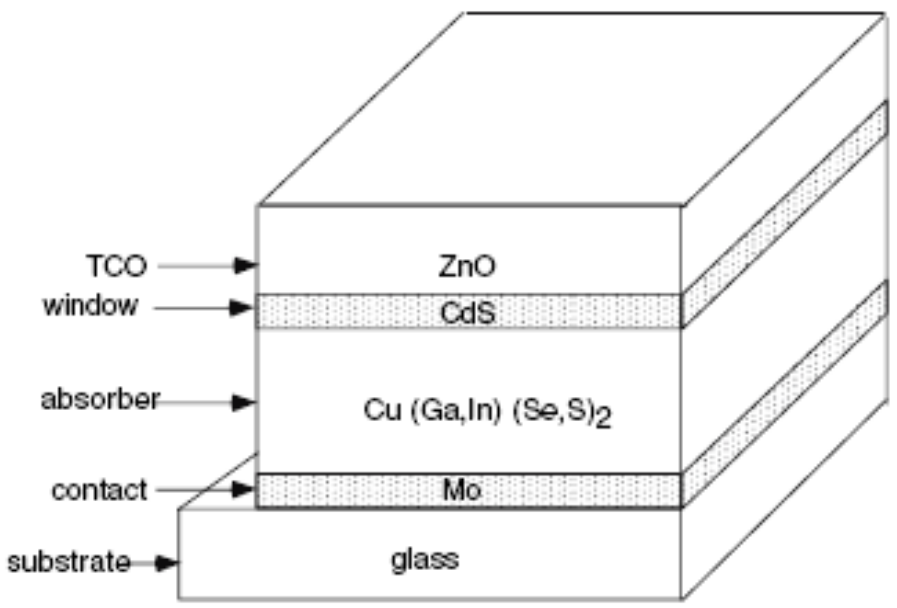

Figure 3. Basic CIS (cupper indium diselenide) cell structure

$\mathrm{CuInSe}_{2}$ with its optical absorption coefficient exceeding $3 \cdot 10^{4} \mathrm{~cm}^{-1}$ at wavelengths below $1000 \mathrm{~nm}$, and its direct band gap between $0,95 \mathrm{eV}$ and $1,2 \mathrm{eV}$, is a good material for solar cells. A CIS solar cell is sensitive in the wavelength of $0,4-1,3 \mu \mathrm{m}$ and maximum of its sensitivity is within the wavelength range of $0,7-0,8 \mu \mathrm{m}$ [4-7].

Commercial CIS solar cells have the $8 \%$ efficiency. However, manufacturing costs of CIS solar cells at present are high when compared with silicon solar cells; however, continuing work is leading to more cost-effective production processes.

Comparative overview of monocrystalline silicon, CdTe and CIS solar cells with their advantages and disadvantages is shown in Table 1 [4-5]. 
Table 1. Comparison between monocrystalline silicon, CdTe and CIS solar cells with their advantages and disadvan-

\begin{tabular}{|c|c|c|c|c|}
\hline Material & Thickness & Efficiency & Colour & Features \\
\hline $\begin{array}{l}\text { Monocrystalline } \\
\text { silicon solar cells }\end{array}$ & $0,3 \mathrm{~mm}$ & $15-18 \%$ & $\begin{array}{c}\text { Dark blue, } \\
\text { black with AR } \\
\text { coating, grey } \\
\text { without AR } \\
\text { coating }\end{array}$ & $\begin{array}{c}\text { Lengthy production procedure, } \\
\text { wafer sawing necessary. Best rese- } \\
\text { arched solar cell material - highest } \\
\text { power/area ratio. }\end{array}$ \\
\hline $\begin{array}{c}\text { Cadmium Telluride } \\
(\mathrm{CdTe}) \\
\text { solar cell }\end{array}$ & $\begin{array}{l}0,008 \mathrm{~mm}+3 \mathrm{~mm} \\
\text { glass substrate }\end{array}$ & $\begin{array}{c}6-9 \% \\
\text { (module) }\end{array}$ & $\begin{array}{c}\text { Dark green, } \\
\text { Black }\end{array}$ & $\begin{array}{l}\text { Poisonous raw materials, signifi- } \\
\text { cant decrease in production costs } \\
\text { expected in the future. }\end{array}$ \\
\hline $\begin{array}{l}\text { Copper-Indium- } \\
\text { Diselenide } \\
\text { (CIS) } \\
\text { solar cell }\end{array}$ & $\begin{array}{l}0,003 \mathrm{~mm}+3 \mathrm{~mm} \\
\text { glass substrate }\end{array}$ & $\begin{array}{l}7,5-9,5 \% \\
\text { (module) }\end{array}$ & Black & $\begin{array}{l}\text { Limited Indium supply in nature. } \\
\text { Significant decrease in production } \\
\text { costs possible in the future. }\end{array}$ \\
\hline
\end{tabular}

\section{PV SOLAR PLANTS}

A PV solar plant is a plant that uses solar cells to convert solar irradiation into electrical energy. PV solar plants consist of solar modules, an inverter converting DC into $\mathrm{AC}$ and transformer conveying the generated power into the grid net. PV solar plant is fully automated and monitored by the applicable software. Inverter is a device which converts DC generated by PV solar plants of $12 \mathrm{~V}$ or $24 \mathrm{~V}$ into three- phase AD of $220 \mathrm{~V}$. Depending on the design, inverter efficiency is up to $97 \%$. When choosing inverter one should bear in mind the output voltage of the solar modules array, power of the solar modules array, grid net parameters, managing type of PV solar plant, etc. PV solar plants can use bigger number of the inverters of smaller power or one or two invertors of greater power. PV solar plant monitoring system comprises central measuring - control unit for the surveillance of the working regime. The monitoring system uses sensors and softwares to obtain the following data: daily, monthly and yearly electricity production, reduction of $\mathrm{CO}_{2}$, detailed change of the system parameters, recording of the events after the failure, monitoring of the meteorological parameters, etc. In accordance with the legal regulations governing power distribution systems, PV solar plants use transformers by means of which solar energy generated by PV solar plant is conveyed to the power grid. It has been shown in practice that the energy efficiency of PV solar plant decreases from $0,5-1 \%$ annually. The real lifetime of silicon-made $\mathrm{PV}$ modules is expected to be at least 30 years.

Depending on climate conditions of the given location, fixed PV solar plants, one-axis and dual-axis tracking PV solar plants are being installed worldwide. Fixed PV solar plants are used in regions with continental climate and tracking PV solar plants are used in tropical regions.

A fixed PV solar plant is a plant with solar modules mounted on fixed metal supporters under an optimal angle in relation to the horizontal surface and all are oriented towards south. To install a fixed 1MW PV solar plant it is necessary to provide about $20000 \mathrm{~m}^{2}$ of space. Its drawback is in that solar modules do not follow the sun radiation so that on the yearly level not the optimum amount of the electricity is gained.

One-axis tracking PV solar plant is a plant where solar modules installed under the optimal angle are oriented towards the sun by revolving around the vertical axis during the day from the east towards the west, following the Sun's azimuth angle from sunrise to sunset. For revolving of solar modules electromotors are used that in turn use electrical energy from the batteries of the power grid. For monitoring revolving of the rotor, a centralized software system is used. In case that the software system fails, solar modules can be directed towards the sun manually. It is also possible to manually set the tilt of the solar modules in relation to the horizontal surface in steps from $5^{\circ}$ from $0-45^{\circ}$. One-axis tracking PV solar plant gives the shadow effect of solar modules situated on neighboring rotors so that for its installation it is necessary to provide around $60000 \mathrm{~m}^{2}$. According to the available literature, the efficiency of oneaxis tracking PV solar plant is $20-25 \%$ higher compared to the efficiency of the fixed PV solar plant. A disadvantage of one-axis tracking PV solar plant is in the fact that there is no automatic orienting of the solar module tilt towards the sun in the course of the year.

Dual-axis tracking PV solar plant is a plant where the position of solar modules is oriented towards the sun by revolving around the vertical and horizontal axis. These PV solar plants follow 
the Sun's azimuth angle from sunrise to sunset but they also adjust the tilt angle to follow the minuteby-minute and seasonal changes in the Sun's altitude angle. Solar modules are oriented towards the sun by means of the appropriate electromotors. Photo sensors mounted on the array send signals to a controller that activates the motors, causing the array angles to change as the Sun's height and azimuth angles change during the day. The efficiency of the dual-axis tracking PV solar plant is $25-30 \%$ higher than the efficiency of the fixed $\mathrm{PV}$ solar plant. The installation and function of tracking PV solar plant require a substantially bigger surface than is the case with the fixed PV solar plant.

PV solar plants represent environmentally clean energy source. PV solar plant components (solar modules, inverters, monitoring system, conductors, etc) are manufactured by cutting-edge, environmentally friendly technologies. PV solar plants operate noiselessly, do not emit harmful substances and do not emit harmful electromagnetic radiation into the environment. Solar plant recycling is also environmentally-friendly. For $1 \mathrm{kWh}$ of PV solar plant generated electrical energy reduces the emission of $0,568 \mathrm{~kg} \mathrm{CO}$ into the atmosphere [1,2,8-10].

\section{PVGIS PROGRAMME}

PVGIS software packages that are easily found on the Internet are used nowadays to calculate the electricity generated by the fixed PV solar plants, one-axis and dual-axis tracking PV solar plants. These programs can produce the following data: average daily, monthly and yearly values of the solar irradiation taken on square meter of the horizontal surface or the surface tilted under certain angle in relation to the horizontal surface, change in the optimal tilting angle of the solar modules during the year, relation of global and diffused sun radiation, average daily temperature, and daily, monthly and yearly electricity generated by fixed PV solar plants, one-axis and dual-axis tracking PV solar plants, etc. A typical PVGIS value for the performance ratio (PV system losses) of PV solar plants with modules made of monocrystalline and policrystalline silicon is taken to be $0,75[1,11-12]$.

\section{RESULTS}

In this section we present the results obtained from the study of the solar irradiation and electricity generated by fixed PV solar plants, oneaxis and dual-axis tracking 1MW PV solar plants with monocrystalline silicon, CdTe and CIS solar modules in the area of Banja Luka, processed by PVGIS software [1,11-12].

The average monthly values of solar irradiation on horizontal, optimally inclined and vertical plane, optimal inclination, ratio of diffuse to global solar irradiation, average daytime temperature and 24 hour average of temperature for Banja Luka (444ㄴ $48^{\prime \prime}$ North, $17^{\circ} 10^{\prime} 17^{\prime \prime}$ East) obtained using the PVGIS program (Annual irradiation deficit due to shadowing (horizontal) is $0,3 \%$ ) are presented in Table 2.

Based on the results in Table 2 one can conclude that the average ratio of diffuse and global solar radiation in Banja Luka during the year is around 0,49 ; that the optimal angle of solar modules in fixed PV solar plant is $33^{\circ}$ and in one-axis tracking PV solar plant $36^{\circ}$; that solar irradiation on optimally inclined plane yields annually 4000 $\mathrm{Wh} / \mathrm{m}^{2}$ and is by $13 \%$ higher than the solar irradiation on horizontal plane and by $52 \%$ higher than the solar irradiation on vertical plane.

Average monthly and yearly sum of global solar irradiation per square meter received by the modules of the fixed PV solar plants, one-axis and dual-axis tracking 1MW PV solar plants in Banja Luka are shown in Table 3.

Based on the results in Table 3 one can conclude that the average sum of global irradiation per square meter received by the modules of the dualaxis tracking PV solar plant $\left(1880 \mathrm{kWh} / \mathrm{m}^{2}\right)$ is by $2,7 \%$ higher than the average sum of global irradiation per square meter received by the modules of the one-axis tracking PV solar plant and by $28,8 \%$ higher than the average sum of global irradiation per square meter received by the modules of the fixed PV solar plant.

The results of calculations for the annual electricity generation by fixed, one-axis and dualaxis tracking 1MW PV solar plants with solar modules of monocrystalline silicon, CdTe and CIS solar modules in Banja Luka are shown in Table 4. 
Table 2. Average monthly values of solar irradiation on horizontal, optimally inclined and vertical plane, optimal inclination, ratio of diffuse to global solar irradiation, average daytime temperature and 24- hour average of temperature for Banja Luka

\begin{tabular}{|c|c|c|c|c|c|c|c|}
\hline Month & $\begin{array}{c}\text { Solar irra- } \\
\text { diation on } \\
\text { horizontal } \\
\text { plane } \\
\left(\mathrm{Wh} / \mathrm{m}^{2}\right)\end{array}$ & $\begin{array}{l}\text { Solar irra- } \\
\text { diation on } \\
\text { optimally } \\
\text { inclined } \\
\text { plane } \\
\left(\mathrm{Wh} / \mathrm{m}^{2}\right)\end{array}$ & $\begin{array}{l}\text { Solar irra- } \\
\text { diation on } \\
\text { vertical } \\
\text { plane } \\
\left(\mathrm{Wh} / \mathrm{m}^{2}\right)\end{array}$ & $\begin{array}{l}\text { Optimal } \\
\text { inclination } \\
\left({ }^{\circ}\right)\end{array}$ & $\begin{array}{l}\text { Ratio of } \\
\text { diffuse to } \\
\text { global } \\
\text { irradiation } \\
\quad(-)\end{array}$ & $\begin{array}{c}\text { Average } \\
\text { daytime } \\
\text { temperature } \\
\left({ }^{\circ} \mathrm{C}\right)\end{array}$ & $\begin{array}{c}24 \text { hour } \\
\text { average of } \\
\text { temperature } \\
\left({ }^{\circ} \mathrm{C}\right)\end{array}$ \\
\hline Jan & 1240 & 1920 & 1920 & 62 & 0,61 & 1,8 & 0,7 \\
\hline $\mathrm{Feb}$ & 1960 & 2740 & 2470 & 54 & 0,57 & 4,2 & 3,0 \\
\hline Mar & 3110 & 3840 & 2940 & 43 & 0,53 & 8,7 & 7,3 \\
\hline Apr & 4300 & 4680 & 2880 & 29 & 0,51 & 13,0 & 11,8 \\
\hline May & 5330 & 5320 & 2710 & 16 & 0,49 & 18,1 & 16,4 \\
\hline Jun & 5780 & 5540 & 2560 & 11 & 0,49 & 21,4 & 19,6 \\
\hline Jul & 6320 & 6210 & 2900 & 15 & 0,41 & 23,2 & 21,7 \\
\hline Aug & 5360 & 5710 & 3210 & 25 & 0,43 & 23,0 & 21,4 \\
\hline Sep & 4070 & 4970 & 3570 & 41 & 0,42 & 18,3 & 17,0 \\
\hline Oct & 2550 & 3520 & 3060 & 53 & 0,50 & 14,7 & 13,4 \\
\hline Nov & 1450 & 2140 & 2060 & 59 & 0,61 & 8,3 & 7,3 \\
\hline Dec & 956 & 1360 & 1290 & 58 & 0,70 & 2,7 & 2,1 \\
\hline Year & 3540 & 4000 & 2630 & 33 & 0,49 & 13,1 & 11,8 \\
\hline
\end{tabular}

Table 3. Average sum of global solar irradiation per square meter received by the modules of the fixed PV solar plants, one-axis and dual-axis tracking $1 M W$ PV solar plants in Banja Luka

\begin{tabular}{|c|c|c|c|}
\hline MONTH & $\begin{array}{l}\text { Average sum of global } \\
\text { irradiation per square } \\
\text { meter received by the } \\
\text { modules of the fixed } \\
\text { PV solar plant } \\
\left(\mathrm{kWh} / \mathrm{m}^{2}\right) \\
\text { (optimal inclination of } \\
\text { modules is } 33^{\circ}\end{array}$ & $\begin{array}{l}\text { Average sum of global } \\
\text { irradiation per square } \\
\text { meter received by the } \\
\text { modules of the one - axis } \\
\text { tracking PV solar plant } \\
\left(\mathrm{kWh} / \mathrm{m}^{2}\right) \\
(\text { optimal inclination of } \\
\left.\text { modules is } 36^{\circ}\right)\end{array}$ & $\begin{array}{c}\text { Average sum of } \\
\text { global irradiation per } \\
\text { square meter recei- } \\
\text { ved by the modules } \\
\text { of the } \\
\text { dual - axis tracking } \\
\text { PV solar plant } \\
\left(\mathrm{kWh} / \mathrm{m}^{2}\right)\end{array}$ \\
\hline Jan & 59,5 & 66,9 & 71,3 \\
\hline Feb & 76,7 & 89,1 & 91,7 \\
\hline Mar & 119 & 146 & 146 \\
\hline Apr & 141 & 177 & 178 \\
\hline May & 165 & 211 & 217 \\
\hline Jun & 166 & 213 & 223 \\
\hline Jul & 193 & 256 & 265 \\
\hline Aug & 177 & 233 & 236 \\
\hline Sep & 149 & 190 & 191 \\
\hline Oct & 109 & 133 & 136 \\
\hline Nov & 64,3 & 72,6 & 76,2 \\
\hline Dec & 42,2 & 44,0 & 46,0 \\
\hline Yearly average & 122 & 153 & 156 \\
\hline Total for year & 1460 & 1830 & 1880 \\
\hline
\end{tabular}


In PVGIS program, in PV solar plant with solar modules of monocrystalline silicon, the following losses were calculated: losses due to temperature amount to $9,4 \%$ (using local ambient temperature); losses due to angular reflectance effects amount to $2,8 \%$; other losses (cables, inverter etc.) amount to $14 \%$ and $24,3 \%$ combined PV system losses.

In PVGIS program, in PV solar plant with CdTe solar modules, the following losses were calculated: losses due to temperature amount to $0,1 \%$ (using local ambient temperature); losses due to angular reflectance effects amount to $2,8 \%$; other losses (cables, inverter etc.) amount to $14 \%$ and $16,3 \%$ combined PV system losses.

In PVGIS program, in PV solar plant with CIS solar modules the following losses were calculated: losses due to temperature amount to $7,8 \%$ (using local ambient temperature); losses due to angular reflectance effects amount to $2,8 \%$; other losses (cables, inverter etc.) amount to $14 \%$ and 22, 9\% combined PV system losses on CIS solar modules.

Annual production of electricity using fixed, one-axis and dual-axis tracking PV solar plant of $1 \mathrm{MW}$ with solar modules of monocrystalline sili- con, CdTe and CIS solar modules in Banja Luka is shown in Figure 4.

On the annual basis $1100 \mathrm{MWh}$ of electrical energy can be generated by fixed PV solar plant with solar modules of monocrystalline silicon, 1220 MWh with CdTe solar modules and 1120 MWh with CIS solar modules . On the basis of the obtained results one can conclude that:

- by one-axis tracking PV solar plant 26,36 $\%$ and by dual-axis tracking PV solar plant $29,09 \%$ more electrical energy can be produced in comparison to the fixed 1MW PV solar plant in Banja Luka with solar modules of monocrystalline silicon;

- by optimally inclined one-axis tracking PV solar plant $25,41 \%$ and by dual-axis tracking PV solar plant $27,87 \%$ more electrical energy can be produced in comparison to the fixed 1MW PV solar plant in Banja Luka with CdTe solar modules and

- by one-axis tracking PV solar plant 26,79 $\%$ and by dual-axis tracking PV solar plant $29,46 \%$ more electrical energy can be produced in comparison to the fixed 1MW PV solar plant in Banja Luka with CIS solar modules.

Table 4. The results of calculations for the annual electricity generation by fixed, one-axis and dual-axis tracking $1 M W$ PV solar plants with solar modules of monocrystalline silicon, CdTe and CIS solar modules in Banja Luka

\begin{tabular}{|c|c|c|c|c|c|c|c|c|c|}
\hline \multirow[t]{2}{*}{ MONTH } & \multicolumn{3}{|c|}{$\begin{array}{c}\text { AVERAGE MONTHLY } \\
\text { ELECTRICITY PRO- } \\
\text { DUCTION FROM FIXED } \\
\text { PV SOLAR } \\
\text { PLANT }\end{array}$} & \multicolumn{3}{|c|}{$\begin{array}{c}\text { AVERAGE MONTHLY } \\
\text { ELECTRICITY PRO- } \\
\text { DUCTION FROM ONE - } \\
\text { AXIS TRACKING PV } \\
\text { SOLAR PLANT } \\
(\mathrm{kWh}) \\
\text { (optimal inclination } \\
\left.\text { of modules is } 36^{\circ}\right)\end{array}$} & \multicolumn{3}{|c|}{$\begin{array}{l}\text { AVERAGE MONTHLY } \\
\text { ELECTRICITY PRO- } \\
\text { DUCTION FROM DUAL } \\
\text { - AXIS TRACKING PV } \\
\text { SOLAR PLANT }\end{array}$} \\
\hline & $\begin{array}{l}\text { c-Si solar } \\
\text { modules }\end{array}$ & $\begin{array}{c}\text { CdTe } \\
\text { solar } \\
\text { modules }\end{array}$ & $\begin{array}{l}\text { CIS solar } \\
\text { modules }\end{array}$ & $\begin{array}{c}\text { c-Si solar } \\
\text { modules }\end{array}$ & $\begin{array}{c}\text { CdTe } \\
\text { solar } \\
\text { modules }\end{array}$ & $\begin{array}{l}\text { CIS solar } \\
\text { modules }\end{array}$ & $\begin{array}{l}\text { c-Si solar } \\
\text { modules }\end{array}$ & $\begin{array}{c}\text { CdTe } \\
\text { solar } \\
\text { modules }\end{array}$ & $\begin{array}{l}\text { CIS solar } \\
\text { modules }\end{array}$ \\
\hline Jan & 48900 & $\begin{array}{r}51400 \\
\end{array}$ & 49300 & 54700 & 57400 & 55300 & 57400 & 60300 & 58300 \\
\hline Feb & 62100 & 65700 & 62600 & 71700 & 75700 & 72600 & 73200 & 77200 & 74300 \\
\hline Mar & 93200 & 100000 & 94400 & 114000 & 122000 & 116000 & 115000 & 122000 & 116000 \\
\hline Apr & 107000 & 117000 & 109000 & 136000 & 147000 & 138000 & 136000 & 148000 & 139000 \\
\hline May & 122000 & 137000 & 125000 & 158000 & 174000 & 162000 & 162000 & 179000 & 166000 \\
\hline Jun & 121000 & 138000 & 124000 & 158000 & 176000 & 162000 & 164000 & 183000 & 169000 \\
\hline Jul & 139000 & 159000 & 143000 & 188000 & 212000 & 194000 & 194000 & 218000 & 200000 \\
\hline Aug & 128000 & 146000 & 131000 & 171000 & 191000 & 176000 & 172000 & 193000 & 178000 \\
\hline Sep & 112000 & 125000 & 114000 & 143000 & 158000 & 147000 & 144000 & 159000 & 147000 \\
\hline Oct & 83900 & 92100 & 85200 & 102000 & 111000 & 104000 & 104000 & 113000 & 106000 \\
\hline Nov & 51500 & 55400 & 52000 & 58000 & 62200 & 58700 & 60200 & 64500 & 61200 \\
\hline Dec & 33600 & 36800 & 34600 & 35100 & 38100 & 36100 & 36200 & 39200 & 37300 \\
\hline $\begin{array}{l}\text { Yearly ave- } \\
\text { rage }\end{array}$ & 91900 & 102000 & 93700 & 116000 & 127000 & 119000 & 118000 & 130000 & 121000 \\
\hline
\end{tabular}




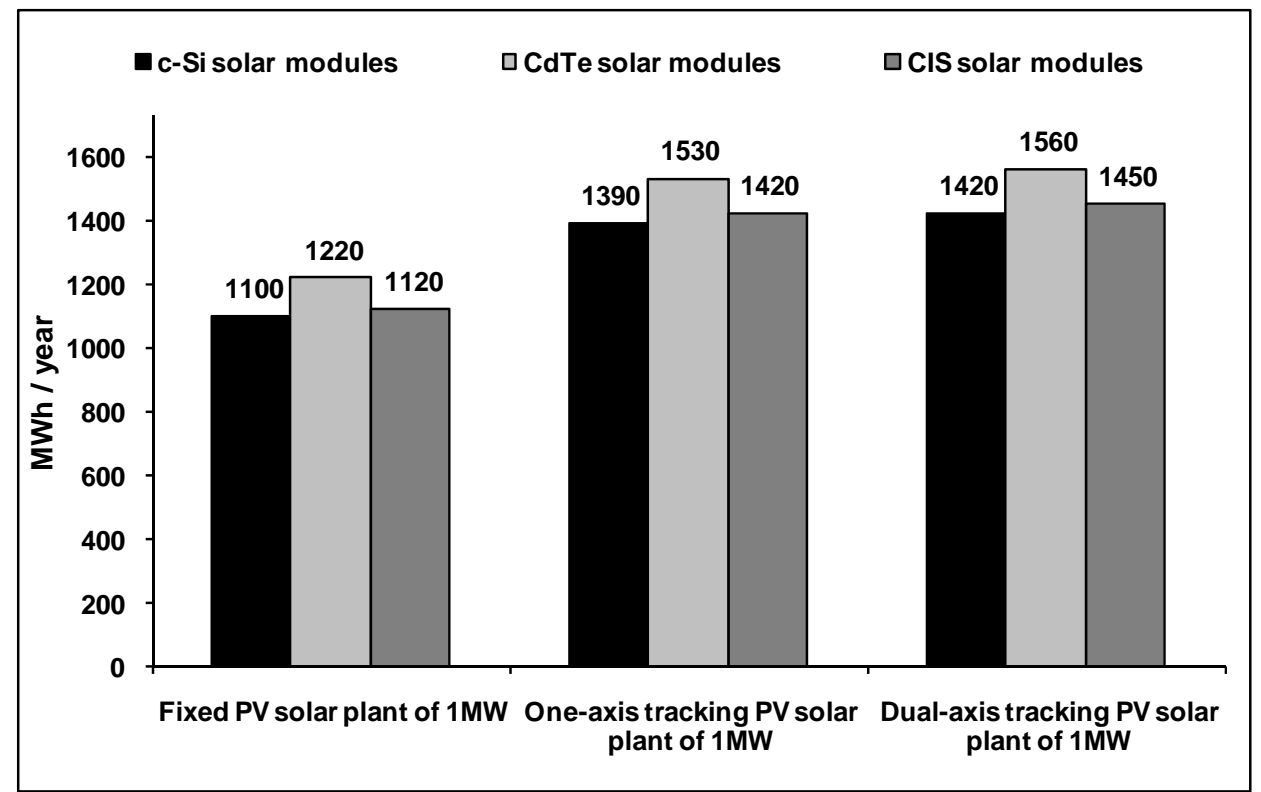

Figure 4. Annual production of electricity using fixed, optimally inclined one-axis and dual-axis tracking $P V$ solar plant of $1 \mathrm{MW}$ with solar modules of monocrystalline silicon, CdTe and CIS solar modules in Banja Luka

\section{INVESTMENTS}

To cost of installing fixed PV solar plant, one-axis tracking PV solar plant and dual-axis tracking PV solar plants of $1 \mathrm{MW}$ is about 3.000.000, 4.000 .000 and 5.000 .000 euro, respectively. To install fixed PV solar plant of $1 \mathrm{MW}$ it is necessary to provide around $20000 \mathrm{~m}^{2}$ of area maintenance cost of the fixed PV solar plants are much lower than the maintenance cost of the tracking PV solar plants. Tracking PV solar plant gives the shadow effect of solar modules situated on neighboring rotors so that for its installation it is necessary to provide around $50.000 \mathrm{~m}^{2}$. Maintenance cost of dual-axis tracking PV solar plants is higher than the maintenance cost of one-axis tracking PV solar plants.

\section{CONCLUSION}

In the light of all aforementioned one can conclude that:

- climate conditions in Banja Luka are favourable for the installation of PV solar plants with monocrystalline silicon, CdTe and CIS solar cells;

- 1 MW fixed solar plant with monocrysta1line silicon solar cells in Banja Luka can produce $1100 \mathrm{MWh}$ annually, one-axis tracking solar plant can produce $1390 \mathrm{MWh}$, and dual-axis tracking solar plant can produce $1560 \mathrm{MWh}$ of electric energy;

- fixed solar plant of $1 \mathrm{MW}$ with CdTe solar cells in Banja Luka can produce1220 MWh annually, one-axis tracking solar plant can produce $1530 \mathrm{MWh}$, and dual-axis tracking solar plant can produce $1420 \mathrm{MWh}$ of electric energy;

- fixed solar plant of $1 \mathrm{MW}$ with CIS solar modules in Banja Luka would produce $1120 \mathrm{MWh}$ annually, one-axis tracking solar plant would yield $1420 \mathrm{MWh}$ and dual-axis tracking solar plant would produce $1450 \mathrm{MWh}$ of electric energy;

- fixed PV solar plant with monocrystalline silicon solar modules of $1 \mathrm{MW}$ in Banja Luka is possible to reduce $\mathrm{CO}_{2}$ emissions in the amount of $624800 \mathrm{~kg}$ per year; CdTe solar modules will reduce $692960 \mathrm{~kg}$ and CIS solar modules will reduce $\mathrm{CO}_{2}$ emissions in the amount of $636160 \mathrm{~kg}$ per year;

- with inclined one-axis tracking PV solar plant with monocrystalline silicon solar modules of $1 \mathrm{MW}$ in Banja Luka it is possible to reduce $\mathrm{CO}_{2}$ emissions in the amount of $789520 \mathrm{~kg}$ per year; with CdTe solar modules $869040 \mathrm{~kg}$ and with CIS solar modules $806560 \mathrm{~kg}$ per year;

- with dual-axis tracking PV solar plant with monocrystalline silicon solar modules of 1 MW in Banja Luka it is possible to reduce $\mathrm{CO}_{2}$ emissions at the level of $806560 \mathrm{~kg}$ per year; with CdTe solar modules $886080 \mathrm{~kg}$ and with CIS solar modules $823600 \mathrm{~kg}$ per year. 
It has been shown in practice that the efficiency of PV solar plants is influenced by climate conditions, type of used solar cells, type of PV solar plants, required surface of the area, maintenance costs, etc. Having in mind that Banja Luka has moderate continental climate with sharp delineated seasons of the year and lots of snowfalls that can seriously affect tracking PV solar plants we believe that it is best to install fixed PV solar plants in Banja Luka. Installing of fixed PV solar plants requires smaller area of land than for the installation of the tracking PV solar plants. Besides, maintenance costs of the fixed PV solar plant are remarkably lower in comparison to the costs incurred by the tracking PV solar plants.

\section{REFERENCES}

[1] T. Pavlović, D. Milosavljević, A. Radivojević, M. Pavlović, Comparison and assessment of electricity generation capacity for different types of $P V$ solar plants of 1MW In Soko Banja, Serbia, Thermal Science, 15-3 (2011) 605-618.

[2] T. Pavlović, B. Čabrić, Physics and techniques of solar energy, Građevinska knjiga, Belgrade, 2006.
[3] J. M. Radosavljević, T. M. Pavlović, M. R. Lambić, Solar energy and sustainable development, Građevinska knjiga, Belgrade, 2010.

[4] http://www.pvresources.com/en/solarcells.php

[5] http://www.scribd.com/doc/58670014/NREL-ThinFilm-Overview-2008

[6] T. Markvart, L. Castaner, Solar Cells, Elsevier, Amsterdam, 2006.

[7] M. Green, Thin-film solar cells: Review of materials, technologies and commercial status, Journal of Materials Science: Materials in Electronics, 18-1 (2007) 15-19.

[8] D. Chiras, R. Aram, K. Nelson, Power from the sun - achieving energy independence, New society publishers, Canada, 2009.

[9] R. Messenger, J. Ventre, Photovoltaic systems engineering, CEC Press, Taylor \& Francis Group, USA, 2010.

[10] T. Pavlović, D. Milosavljević, Development of PV solar power plants in the world, Conference Proceedings „Contemporary Materials 2010”, Banja Luka 2011, 249-259.

[11] http://re.jrc.ec.europa.eu/pvgis/apps3/pvest.php [12] http://sunbird.jrc.it/pvgis/apps/pvest.php?europe

ПРИМЈЕНА СОЛАРНИХ ЋЕЛИЈА ОД РАЗЛИЧИТИХ МАТЕРИЈАЛА КОД ФОТОНАПОНСКИХ СОЛАРНИХ ЕЛЕКТРАНА ОД 1 МW У БАЮОЈ ЛУЦИ

Сажетак: У раду су дате енергетске ефикасности фиксне, једноосно и двоосно ротационе соларне електране од 1 MW у Бањој Луци са соларним ћелијама од монокристалног силицијума и танкослојним CdTe и $\mathrm{CuInSe}$ (CIS) соларним ћелијама. У раду је пажња посвећена физичким карактеристикама соларних ћелија од монокристалног силицијума, CdTe и CIS соларним ћелијама и њиховој примени код соларних електрана. За израчунавање енергетске ефикасности соларних електрана коришћен је PVGIS програм.

Кључне речи: соларна енергија, соларне ћелије, соларне електране. 